\title{
Knappebatteri i oesophagus
}

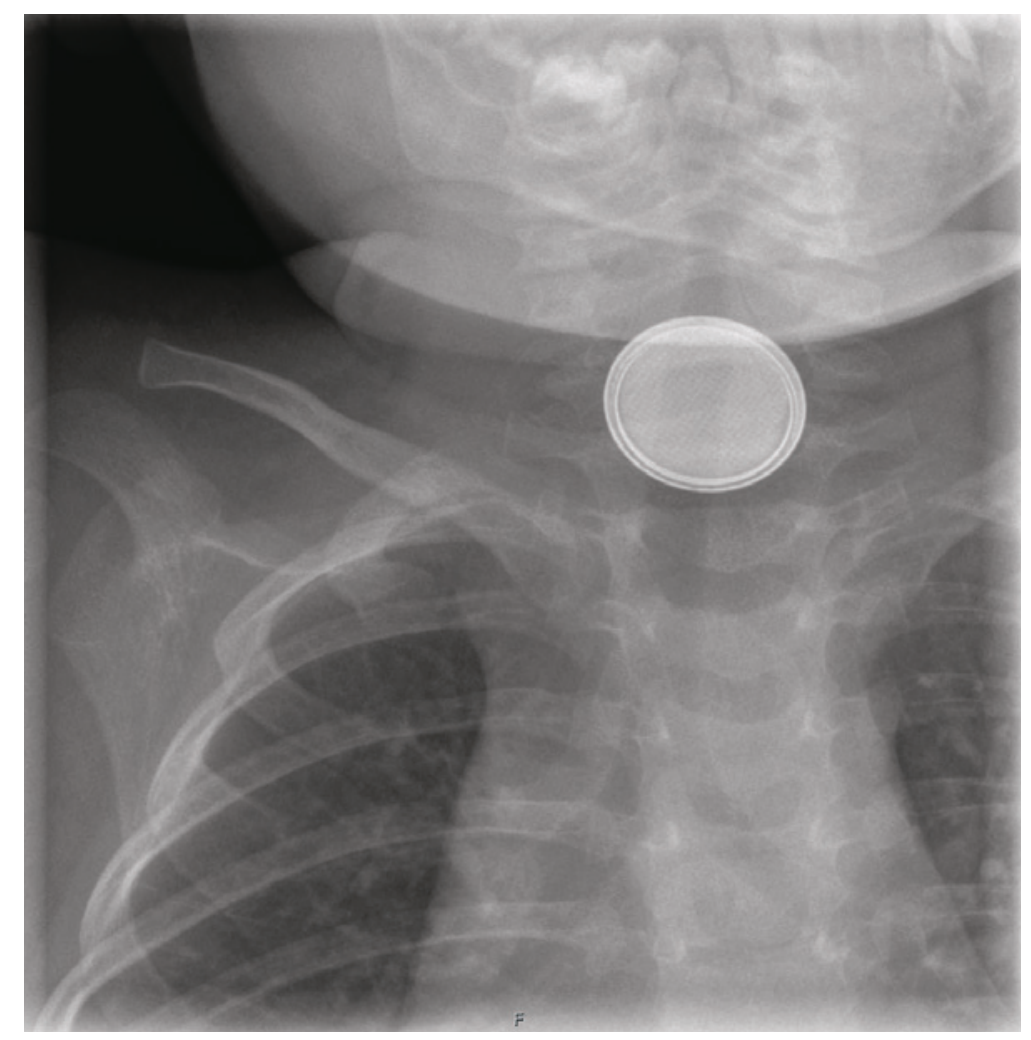

En 14 måneder gammel jente ble innlagt ved en øre-nese-hals-avdeling med mistanke om at et knappebatteri satt fast i spiserøret. Moren hadde funnet henne mens hun holdt en TV-fjernkontroll som manglet batteri. Jenta siklet, var utilpass, kastet opp og gråt.

Det ble tatt røntgenbilde som viste et røntgentett fremmedlegeme forenlig med et $20 \mathrm{~mm}$ stort knappebatteri i øvre del av oesophagus.

Fem timer fra det tidspunktet batteriet ble svelget ble pasienten endoskopert i narkose og batteriet fjernet. Det ble påvist slimhinnenekrose svarende til batteriets diameter med ekstensjon ned til muskellaget. Pasienten fikk nasogastrisk sonde og det ble gitt antibiotikaprofylakse. Det postoperative forløpet var ukomplisert og jenta ble utskrevet femte dag etter hendelsen. To uker senere ble det gjort ny skopi. Slimhinnene var da tilhelet, sonden ble fjernet og pasienten kunne gå over til vanlig mat. To måneder senere hadde pasienten ingen sekveler.

Ved mistanke om fastsittende fremmedlegeme i form av et knappebatteri i oesophagus må dette utredes og behandles umiddelbart. Symptomer kan være luftveisobstruksjon/stridor, sikling, oppkast, ubehag, dysfagi og hoste. Når et barn har svelget et batteri, skal man ikke forsøke å provosere brekninger, men bringe vedkommende til umiddelbar øsofagoskopi og ekstraksjon. Batterier som har passert til ventrikkelen, observeres av foreldrene inntil det passerer spontant med avføringen (1).

Det er påvist at de sårbare slimhinnene $\mathrm{i}$ oesophagus kan nekrotisere allerede etter to timer. Årsaken til knappebatterienes store vevsnekrotiserende potensial er at det etableres en strømkrets (1). Risiko for skade er størst ved batteriets negative pol. Fryktede komplikasjoner er oesophagusperforasjon, mediastinitt og skade på omkringliggende strukturer. Røntgenbildet viser et røntgentett, rundt fremmedlegeme med halo. På et sidebilde vil man ved et slikt tilfelle kunne identifisere batteriets negative pol, som har mindre diameter og fremstår med et «step-off»».

Pasientens pårørende har samtykket til at artikkelen blir publisert.

\section{Eirik Mathisen}

eirik.mathisen@so-hf.no

$\emptyset$ re-nese-halsavdelingen

Sykehuset Østfold

Patrick Edward Tetzlaff

$\emptyset$ re-nese-halsavdelingen

Sykehuset Østfold

\section{Kjell Brøndbo}

$\emptyset$ re-nese-halsavdelingen

Laryngologisk seksjon

Oslo universitetssykehus, Rikshospitalet
Eirik Mathisen (f. 1974) er spesialist i øre-nesehalssykdommer og overlege.

Forfatter har fylt ut ICMJE-skjemaet og oppgir ingen interessekonflikter.

Patrick Edward Tetzlaff (f. 1981) er lege i spesialisering i øre-nese-halssykdommer.

Forfatter har fylt ut ICMJE-skjemaet og oppgir ingen interessekonflikter.

Kjell Brøndbo (f. 1947) er dr.med., spesialist i øre-nese-halssykdommer, professor og seksjonsoverlege.

Forfatter har fylt ut ICMJE-skjemaet og oppgir ingen interessekonflikter.

Litteratur

1. Jatana KR, Litovitz T, Reilly JS et al. Pediatric button battery injuries: 2013 task force update. Int J Pediatr Otorhinolaryngol 2013; 77: 1392-9.

Mottatt 20.12. 2014, første revisjon innsendt 5.3. 2014, godkjent 31.3. 2015. Redaktør: Lise Mørkved Helsingen. 